\title{
FLOWERING LOCUS T, GIGANTEA, SEPALLATA, and FRIGIDA homologs are candidate genes involved in white lupin (Lupinus albus L.) early flowering
}

\author{
Sandra Rychel • Michał Książkiewicz (iD) • \\ Magdalena Tomaszewska • Wojciech Bielski • \\ Bogdan Wolko
}

Received: 3 October 2018 / Accepted: 19 February 2019 / Published online: 5 March 2019

(C) The Author(s) 2019

\begin{abstract}
White lupin (Lupinus albus L.) is a legume plant rich in seed protein and appreciated in crop rotation due to improvement of soil structure and fertility. Primitive white lupin accessions are late flowering unless subjected to cold period during seed germination. It is an undesirable trait in spring-based agriculture. Moreover, white lupin is very susceptible to anthracnose, and the only known resistant lines are late-flowering landraces from Ethiopia. Tracking of early flowering during white lupin breeding has been challenging for many years due to the lack of knowledge on underlying genes and limited molecular resources. To address this issue, we performed genomic and genetic analysis of white lupin germplasm differing by time to flowering, including mapping population derived from Kiev Mutant (early flowering, anthracnose susceptible) and P27174 (late flowering, anthracnose resistant). Thirty six flowering induction pathway genes were subjected to molecular marker development and linkage mapping. Markers representing 24 homologs were localized in 17 linkage groups. Four quantitative trait loci (QTLs) of flowering
\end{abstract}

Sandra Rychel and Michał Książkiewicz contributed equally to this work.

Electronic supplementary material The online version of this article (https://doi.org/10.1007/s11032-019-0952-0) contains supplementary material, which is available to authorized users.

S. Rychel • M. Książkiewicz $(\bowtie) \cdot$ M. Tomaszewska • W. Bielski • B. Wolko Institute of Plant Genetics, Polish Academy of Sciences, Strzeszyńska 34, 60-479 Poznań, Poland

e-mail: mksi@igr.poznan.pl time, consistent across field and greenhouse experiments, were localized in three linkage groups. Three QTLs absolutely co-localized with GIGANTEA, FLOWERING LOCUS T, and SEPALLATA 3 genebased markers whereas one neighbored the FRIGIDA 3 marker by $3.6 \mathrm{cM}$. Analysis of narrow-leafed lupin genome regions highly syntenic to these QTLs highlighted these homologs as candidate genes for early flowering. Molecular markers developed in the present study should have facilitated the issue of tracking lateflowering alleles in further white lupin breeding approaches involving primitive Ethiopian germplasm.

Keywords Flowering · White lupin · Molecular markers · Quantitative trait loci · Candidate genes · Synteny

\section{Introduction}

Lupins are valuable crops, recognized as a source of protein as well as plants which improve soils and enhance yields of the succeeding sowings in organic farming. Wild accessions of three main Old World lupin crops, i.e., narrow-leafed (Lupinus angustifolius L., L. angustifolius), white (Lupinus albus L., L. albus), and yellow (Lupinus luteus L., L. luteus) lupins, require a period of approximately 3 weeks with low temperature (about $5{ }^{\circ} \mathrm{C}$ ) to promote flowering (Adhikari et al. 2012). This phenomenon, known as vernalization requirement, is an advantageous natural adaptation to harsh climate conditions, but it is undesirable in 
spring-based agriculture. Identification of thermoneutral germplasm lacking vernalization requirement was a major achievement in L. angustifolius domestication (Gladstones and Hill 1969). Early-flowering dominant genes in this species were named Julius (in Europe) and $K u$ (in Australia). Their implementation into breeding programs enabled late spring sowing of L. angustifolius in Europe as well as the introduction of this species as a crop into countries with warm climate such as Australia (Boersma et al. 2007; Święcicki and Święcicki 1995). Recent studies revealed that just a single gene from FLOWERING LOCUS T (FT) subclade, named LanFTc1, underlies locus Ku/Julius (Nelson et al. 2017; Taylor et al. 2019). Vernalization requirement is also a common feature of white lupin (Adhikari et al. 2012). With the release of the first early-flowering L. albus cultivar, Ukrainian Kiev Mutant, carrying hypothetical gene brevis, the species became one of the major, high yielding lupin crops grown worldwide (Gladstones et al. 1998). In addition to brevis, other recessive genes carrying early-flowering phenotype (floridus, festinus, and contractus) were described in white lupin germplasm; however, their relation to the Kiev Mutant brevis gene remains unknown (Święcicki 1986). Accessions with considerably reduced time to flowering, including Start (cultivar) and P28283 (French breeding line), were identified in domesticated germplasm (Adhikari et al. 2011, 2013). Crossing of these two accessions with late-flowering lines revealed that early flowering in these lines is controlled by two complementary dominant genes $E f 1$ and $E f 2$, different than the brevis gene present in Kiev Mutant and Ultra (Adhikari et al. 2011).

White lupin is very susceptible to anthracnose, caused by the pathogenic fungus, Colletotrichum lupini (Bondar) Nirenberg, Feiler \& Hagedorn (Nirenberg et al. 2002). This disease appeared to be very devastating for lupin fields in weather patterns optimal for growth and propagation of $C$. lupini (Gondran et al. 1996). This disease critically hampered agronomic improvement of this species, as all genetic sources of resistance are buried in late-flowering, bitter, and lowyielding Ethiopian landraces (Phan et al. 2007).

To facilitate studies on early flowering and anthracnose resistance, a recombinant inbred line (RIL) mapping population derived from the cross between Kiev Mutant (sweet, early flowering, almost thermoneutral, anthracnose susceptible) and Ethiopian landrace P27174 (bitter, late flowering, vernalization responsive, anthracnose resistant) was developed (Adhikari et al. 2009; Phan et al. 2007; Kroc et al. 2017). Phenotyping of this population revealed that early flowering in L. albus is controlled by several quantitative trait loci (QTLs). The presence of three major QTLs, explaining $31-42 \%, 9-21 \%$, and $7-14 \%$ of total flowering time variation, was confirmed by independent experiments in Poland and Australia (Phan et al. 2007; Książkiewicz et al. 2017). The strongest QTL putatively corresponds to the hypothetical brevis gene. Attempts to combine early flowering from Kiev Mutant with anthracnose resistance from P27174 were unsuccessful due to low frequency of early flowering lines in the progeny and the lack of markers for molecular selection (Adhikari et al. 2009, 2013). Although the positions of the trait loci on the linkage map of this species have been resolved, the genes underlying these loci have so far remained undiscovered (Croxford et al. 2008; Phan et al. 2007; Vipin et al. 2013; Książkiewicz et al. 2017). Moreover, molecular tracking of early-flowering alleles has not been possible due to the lack of gene-based markers.

To address this issue, we performed genomic and genetic analysis of white lupin germplasm differing by time to flowering. Transcriptomes of early and lateflowering lines were mined to identify polymorphic loci in L. albus homologs of flowering time control and vernalization response genes. Comparative mapping to the genome sequence of the sister crop species, L. angustifolius, was performed to find which homologs are located in flowering time QTLs. Based on these results, molecular markers anchored in recognized coding sequences were developed and localized on the linkage map. Putative involvement of candidate genes in flowering time regulation is discussed.

\section{Materials and methods}

\section{Plant material}

Genetic mapping was performed using the reference L. albus Kiev Mutant $\times$ P27174 recombinant inbred line (RIL) population $\left(\mathrm{F}_{8}, n=196\right)$, delivered by the Department of Agriculture and Food Western Australia. This population was derived from a cross between a lateflowering, vernalization-responsive Ethiopian landrace, P27174, and an early-flowering, domesticated Ukrainian line, Kiev Mutant, having reduced vernalization requirement (Phan et al. 2007; Vipin et al. 2013; 
Książkiewicz et al. 2017). Eleven L. albus lines were assessed for vernalization responsiveness: Kiev Mutant, FRA6713B, Population 775, BGRC 3911, Al.-26, Population 8032, Population 199, P27174, R-114, Mutant softseed, and Population B-267/79. L. albus lines were derived from the European Lupin Gene Resources Database maintained by Poznan Plant Breeding Ltd. station located in Wiatrowo (Supplementary Table 1).

Assay of vernalization responsiveness

L. albus lines were surveyed for time to flowering and vernalization responsiveness in 2015 and 2018. Vernalization was carried out before sowing, by placing imbibed seeds for 21 days at $5{ }^{\circ} \mathrm{C}$ in darkness on moist filter paper in Petri dishes. Control plants were sown 4 days before the end of vernalization procedure and grown at temperature $\sim 18{ }^{\circ} \mathrm{C}\left(\sim 10{ }^{\circ} \mathrm{C}\right.$ above vernalization threshold) to maintain a similar thermal time (Huyghe 1991). Both treatments were grown in glasshouse conditions at the Institute of Plant Genetics of the Polish Academy of Sciences (Poznan, Poland; 52 $26^{\prime}$ $\mathrm{N}, 16^{\circ} 54^{\prime} \mathrm{E}$ ) under ambient long-day photoperiod (14$16 \mathrm{~h}$ ) for 110 days. Time to flowering was recorded when the first fully opened flower was observed on a plant.

Sequence annotation of flowering regulation pathway genes

Based on the literature data, the set of 80 gene sequences (including duplicates) evidenced to be involved in flowering time control in Arabidopsis thaliana (L.) Heynh., Glycine $\max (\mathrm{L}$.) Merr., and L. angustifolius (Książkiewicz et al. 2016; Nelson et al. 2017) has been selected. Sequences of genes were subjected to sequence homology searches against transcriptome sequences of parental lines of L. albus mapping population (Książkiewicz et al. 2017) as well as the reference transcriptome of L. albus roots and leaves (http://comparative-legumes.org, gene index LAGI01) (O'Rourke et al. 2013). BLASTn algorithm (Altschul et al. 1990) implemented in Geneious v8.1 (Kearse et al. 2012) was used with the following parameters: maximum e-value, 1e-20, word size, 11; match/mismatch, $2 /-3$; gap cost open/extend, 5/2. For every gene, matched sequences were extracted and aligned in Geneious using MAFFT 7.017 (Katoh et al. 2002) with specified parameters: genetic code, standard; algorithm,
E-INS-I; scoring matrix, $1 \mathrm{PAM} / k=2$; gap open penalty, 1.25; offset value, 0. Based on the alignment results, sequences were grouped into particular subclades and realigned. Consensus sequences from every subclade were subjected to protein-based Hidden Markov Model gene prediction in FGENESH+ (Solovyev 2004), using appropriate A. thaliana, G. max, and L. angustifolius protein sequences as references. Consensus sequences were also blasted against the $L$. angustifolius genome assembly L. angustifolius (Hane et al. 2017) with the following parameters: maximum e-value, 1e-20, word size, 7; match/mismatch, 2/-3; gap cost open/extend, $5 / 2$. For every matched gene region, one $L$. angustifolius scaffold with the highest score value was selected for further analysis. To map intron/exon boundaries, predicted mRNAs as well as original L. albus RNA-seq assembly sequences were mapped to the corresponding L. angustifolius scaffolds using progressive Mauve algorithm with gapped aligner MUSCLE 3.6 (Darling et al. 2004; Edgar 2004).

Molecular marker development and linkage mapping of flowering gene homologs in L. albus genome

Mauve alignments consisting of reference flowering gene homologs, L. albus Kiev Mutant, P27174 and LAGI01 transcripts, and L. angustifolius scaffolds were screened for the presence of polymorphic loci. The primers flanking these loci were designed using Primer3Plus (Untergasser et al. 2007) and L. albus cDNA sequences as templates. In case of the lack of recognized polymorphic loci between sequences originating from parental lines of mapping population, primers were anchored in different exons to target one or more introns. Plant DNA isolation was performed using DNeasy Plant Mini Kit (Qiagen, Hilden, Germany). Amplification was performed using DNA isolated from L. albus Kiev Mutant and P27174. If primers yielded single products, amplicons were purified directly from the post-reaction mixtures (QIAquick PCR Purification Kit; Qiagen). When two or more PCR products were obtained in one reaction, the appropriate DNA bands were excised from the gel and extracted (QIAquick Gel Extraction Kit; Qiagen). Purified amplicons were sequenced (ABI PRISM 3130 XL Genetic Analyzer; Applied Biosystems, Hitachi) by the Laboratory of Molecular Biology Techniques, Faculty of Biology, Adam Mickiewicz University (Poznan, Poland). Length polymorphisms were visualized directly 
by $1 \%$ agarose gel electrophoresis. Nucleotide substitution polymorphisms were resolved by the cleaved amplified polymorphic sequence (CAPS) (Konieczny and Ausubel 1993) or derived CAPS (dCAPS) (Neff et al. 1998) approaches. Restriction sites and dCAPS primers were identified using dCAPS Finder 2.0 (Neff et al. 2002). Restriction products were separated by agarose gel electrophoresis, with the agarose concentration (1$3 \%$ ) adjusted to follow the size of the expected digestion products. The calculation of the chi-square $\left(\chi^{2}\right)$ for Mendelian segregation in $\mathrm{F}_{8}$ RILs was performed using the following expected segregation ratios: 0.4961 (paternal), 0.4961 (maternal), 0.0078 (heterozygote). Calculation of probability was based on $\chi^{2}$ and 2 degrees of freedom. L. albus mapping data (Phan et al. 2007; Vipin et al. 2013; Książkiewicz et al. 2017) were imported to Map Manager QTXb20 (Manly et al. 2001). New markers were distributed using Kosambi function and $P$ value of 0.05 . Linkage groups were drawn using MapChart (Voorrips 2002).

Flowering time QTL mapping

Data on flowering time and anthracnose resistance (Książkiewicz et al. 2017) and updated linkage map from this study were used to re-draw QTL loci. Three datasets contained data on time to flowering recorded from experiments without pre-sowing vernalization, namely "nonv_05," arithmetic mean from field experiments performed in Perth, Western Australia ( $31^{\circ} 59^{\prime} \mathrm{S}$, $\left.115^{\circ} 53^{\prime} \mathrm{E}\right)$ in years 2004 and $2005(n=190$, day length 10-11 h); "nonv_15," field experiment performed at Plant Breeding Smolice Ltd. station located in Przebędowo, Poland $\left(52^{\circ} 35^{\prime} \mathrm{N}, 17^{\circ} 01^{\prime} \mathrm{E}\right)$ in 2015 ( $n=175$, day length 14-16 h); "nonv_16," greenhouse experiment performed at the Institute of Plant Genetics, Polish Academy of Sciences in Poznań (52 $26^{\prime} \mathrm{N}, 16^{\circ}$ $\left.54^{\prime} \mathrm{E}\right)$ in year 2016 ( $n=192$, day length $\left.14-16 \mathrm{~h}\right)$. One dataset, "vern_15," contained values of time to flowering from Przebędowo field experiment with vernalization performed by placing imbibed seeds for 21 days at $5{ }^{\circ} \mathrm{C}$ in darkness on moist filter paper in Petri dishes and sowing of vernalized plants 5 days after nonvernalized plants to maintain a similar thermal time $(n=$ 178 , day length 14-16 h). To address anthracnose resistance QTLs, a dataset "antr_avg” carrying arithmetic mean of resistance scores from anthracnose resistance screening performed in Perth, Western Australia, in years 2004 and $2005(n=191)$ was used. Different numbers of lines $(n)$ present in these datasets result from different seed availability and plant survival in performed experiments. Composite interval mapping was performed in Windows QTL Cartographer V2.5 (North Carolina State University, Raleigh, USA) using 20 background control markers, window size $10 \mathrm{cM}$, and walk speed $0.5 \mathrm{cM}$. Linkage groups and LOD graphs were drawn in MapChart (Voorrips 2002). Permutation test $(\times 1000)$ was performed using the same parameters.

\section{Comparative mapping}

Marker sequences were aligned to white lupin transcriptome assemblies, LAGI01 (O'Rourke et al. 2013), Kiev Mutant, and P27174 (Książkiewicz et al. 2017), allowing one nucleotide mismatch per marker and one lacking nucleotide per alignment. One best hit per marker was selected. A Fasta file carrying marker sequences and assigned transcripts (if applicable) was used for comparative mapping by BLAST (Altschul et al. 1990) to the NLL genome assembly (Hane et al. 2017). Sequence collinearity blocks were visualized using Circos (Krzywinski et al. 2009).

\section{Results}

Vernalization responsiveness

The selection of white lupin lines for phenotyping was based on the information on time to flowering in field conditions obtained from the European Lupin Gene Resources Database (Poznan Plant Breeding Ltd., Wiatrowo). Results of both greenhouse vernalizationresponsiveness experiments were consistent with those data. Based on the time to flowering in controlled environment without pre-sowing vernalization, plants were divided into three groups, early (Kiev Mutant, FRA6713B, Population-775, and BGRC-3911), intermediate (Al-26, Population-8032, and Population-199), and late (Population-B-267/79, P27174, R-114, Mutant soft-seed) flowering (Table 1). Differences in flowering time between early and intermediate as well as between intermediate and late lines were statistically significant (Student's $t$ test $P$ value threshold 0.05). Differences in flowering time between accessions within the early and intermediate groups were not statistically significant. Vernalization responsiveness was statistically significant for all lines except FRA6713B which was revealed 
to be thermoneutral in both experiments. Both trials confirmed that parental lines of mapping population, Kiev Mutant and P27174, significantly differ by flowering time and vernalization requirements. Kiev Mutant was classified in both experiments as an early line with low vernalization response whereas P27174 as a late line, highly responsive to vernalization. Vernalization resulted in advanced flowering by $\sim 0$ days in the thermoneutral FRA6713B accession, $\sim 7$ days in early lines, $\sim 14$ days in intermediate, and $\sim 30$ days in late lines.

Sequence annotation of flowering regulation pathway genes

To prepare source files for marker development, L. albus transcriptome assemblies were screened with the use of 58 A. thaliana, 13 G. max, and 9 L. angustifolius CDS sequences representing 80 genes or homologs. BLAST mapping, followed by alignments to NCBI RefSeq database of matched transcripts, resulted in the identification of $L$. albus transcripts for 60 nonredundant genes (Supplementary Table 2). The lacking sequences included, among others, some important flowering time regulators, like FLOWERING LOCUS $C$ (FLC), several AGAMOUS-like ( $A G L$ ) homologs, EMBRYONIC FLOWER 1 (EMF1), FLOWERING PROMOTING FACTOR 1 (FPF1), one FT homolog (LANFTa2), LIKE HETEROCHROMATIN PROTEIN 1 (LHP1), TWIN SISTER OF FT (TSF), and VERNALIZATION 2 (VRN2).

Thirty-six homologs of genes involved in flowering regulation pathways were subjected to more comprehensive assessment. Representative L. albus sequences with the highest score values were used as templates for BLAST screening of Kiev Mutant, P27174, and LAGI01 transcriptome assemblies. The number of identified sequences varied either between genes or genotypes (Supplementary Table 3). EARLY FLOWERING 6 (ELF6), FCA, VERNALIZATION INSENSITIVE 3 (VIN3), FY, and FLAVIN-BINDING KELCH DOMAIN $F B O X(F K F)$ revealed the highest number of transcript variants (20 or more in all three assemblies), whereas FTa1, LEAFY (LFY), BROTHER OF FT AND TFL1 (BFT), FRIGIDA (FRI), VERNALIZATION INDEPENDENCE 3 (VIP3), EARLY FLOWERING 4 (ELF4) the lowest (1 to 3 ). The total number of transcripts assigned to flowering gene homologs in the reference gene index LAGI01, counting 198, was almost twice as high as those found in Kiev Mutant (116) or P27174 (111). However, some important genes were not recognized in LAGI01 but were identified in early-flowering line Kiev Mutant, namely TERMINAL FLOWER 1 (TFL1), $F T a 1$, and $L F Y$. It may indicate the lack of full vernalization of plants used for transcriptome sequencing (O'Rourke et al. 2013). The same phenomenon was observed for the assembly of late-flowering P27174 line and BFT, FTa1, TFL1, and LFY genes. Based on the multiple nucleotide alignments to corresponding L. angustifolius pseudochromosomes or scaffolds, transcripts were clustered and consensus sequences for protein-based Hidden Markov Model gene prediction were retrieved. The majority of multiplied transcript sequences were just different splicing variants. Therefore, the number of predicted CDS copies varied from one for SEPALLATA 3 (SEP3), BFT, ELF1, ELF3, FTa1, FTc1, FTC2, FRI, FRI3, FLOWERING LOCUS D (FLD), PHYTOCHROME INTERACTING FACTOR 4 (PIF4), VIP3, LFY; to five for ELF6, VIN3, FKF, WD40 REPEAT-CONTAINING PROTEIN (MSI4), VERNALIZATION 1 (VRN1); and to seven for EARLY IN SHORT DAYS 4 (ESD4). Obtained dataset of transcriptome-derived sequences constituted a platform for molecular marker development. Predicted coding sequences of white lupin homologs of flowering induction pathway genes are provided in Supplementary Table 4.

Linkage mapping of flowering regulation pathway genes

One hundred eighty-one primer pairs were designed to amplify 36 gene homologs. Sequences and characteristics of primers designed for white lupin marker development are provided in Supplementary Table 5. Single band PCR amplicons were obtained for 104 primer pairs (all genes except SOC1 and MSI4). Direct Sanger sequencing revealed that 11 primer pairs amplified two or more PCR products. Marker sequences were deposited in the DNA Data Bank of Japan under accession numbers (LC434127-LC434318) and in Supplementary Table 6. Multiple sequence alignment anchored 75 markers to white lupin predicted CDSs, 91 markers to white lupin transcripts, and 95 markers to narrow-leafed lupin genome. The difference between the numbers of matching CDS, transcript, and genome sequences is an expected outcome because some markers were designed to target introns which are usually not present in the 
Table 1 Time to flowering and vernalization responsiveness of white lupin accessions

\begin{tabular}{|c|c|c|c|c|c|c|}
\hline Acc. & Line & $\begin{array}{l}\text { Days to flowering } \\
2015\end{array}$ & $\begin{array}{l}\text { Vernalization } \\
\text { response } 2015\end{array}$ & $\begin{array}{l}\text { Days to flowering } \\
2018\end{array}$ & $\begin{array}{l}\text { Vernalization } \\
\text { response } 2018\end{array}$ & $\begin{array}{l}\text { Phenological } \\
\text { classification }\end{array}$ \\
\hline 95479 & Kiev Mutant & $44.6 \pm 0.9$ & $-6.6^{\mathrm{a}}$ & $43.6 \pm 1.7$ & $-6.6^{\mathrm{a}}$ & Early \\
\hline 95525 & FRA6713B & $47.0 \pm 7.2$ & -0.7 & $38.4 \pm 1.3$ & -0.1 & Early \\
\hline 95602 & Population-775 & $45.0 \pm 0.0$ & $-5.0^{\mathrm{a}}$ & $43.9 \pm 3.8$ & $-8.9^{\mathrm{a}}$ & Early \\
\hline 95187 & BGRC-3911 & $44.5 \pm 1.9$ & $-4.1^{\mathrm{a}}$ & $43.0 \pm 0.0$ & $-10.0^{\mathrm{a}}$ & Early \\
\hline 95151 & Al-26 & $59.5 \pm 6.8$ & $-14.0^{\mathrm{a}}$ & $56.8 \pm 4.2$ & $-19.8^{\mathrm{a}}$ & Intermediate \\
\hline 95049 & Population-8032 & $57.5 \pm 4.9$ & $-12.8^{\mathrm{a}}$ & $54.7 \pm 3.9$ & $-15.9^{\mathrm{a}}$ & Intermediate \\
\hline 95143 & Population-199 & $52.8 \pm 1.1$ & $-7.0^{\mathrm{a}}$ & $52.2 \pm 1.8$ & $-13.4^{\mathrm{a}}$ & Intermediate \\
\hline 95072 & Population-B-267/79 & $67.5 \pm 4.0$ & $-20.5^{\mathrm{a}}$ & $68.8 \pm 1.7$ & $-27.6^{\mathrm{a}}$ & Late \\
\hline 95519 & P27174 & $72.6 \pm 0.9$ & $-18.6^{\mathrm{a}}$ & $78.7 \pm 2.1$ & $-33.0^{\mathrm{a}}$ & Late \\
\hline 95157 & $\mathrm{R}-114$ & $85.3 \pm 8.3$ & $-32.5^{\mathrm{a}}$ & $>90$ & $<-42^{\mathrm{a}}$ & Late \\
\hline 95116 & Mutant soft-seed & $86.4 \pm 5.9$ & $-36.4^{\mathrm{a}}$ & $75.5 \pm 2.1$ & $-35.1^{\mathrm{a}}$ & Late \\
\hline
\end{tabular}

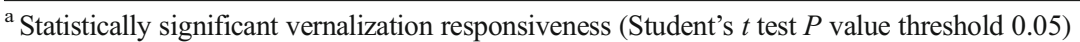

CDS but may occur in the transcriptome assembly. Alignment data for white lupin transcriptome, white lupin CDS, and narrow-leafed lupin genome sequences assigned to white lupin markers are provided in Supplementary Table 7.

From the 96 correctly sequenced markers, 60 were monomorphic. Length polymorphism was identified for 6 markers, whereas single nucleotide substitutions (SNPs) for 30 markers. To visualize these SNPs, 22 CAPS and 5 dCAPS markers were developed (Table 2). The summary of white lupin markers developed for flowering induction pathway genes is provided in Supplementary Table 8 whereas the list of all possible restriction enzymes for polymorphism detection in Supplementary Table 9. Markers were mapped in 17 linkage groups with maximum LOD values to adjacent loci in the range from 32.4 to 58.7 (average LOD value of 48.1). These linkage groups included also ALB02, ALB13, and ALB16 carrying four major earlyflowering QTLs. RIL segregation data for white lupin non-redundant markers from the most recent linkage map (Książkiewicz et al. 2017) including those developed for flowering induction pathway gene is provided in Supplementary Table 10.

QTL mapping and identification of candidate genes

Linkage map updated with markers developed in this study has been subjected to QTL mapping based on the flowering time data from two field and one greenhouse experiments without pre-sowing vernalization (datasets nonv_05, nonv_15, nonv_16, respectively) and from one field experiment with vernalization applied (dataset vern_15) (Książkiewicz et al. 2017). Genome-wide permutation test provided the following LOD confidence threshold values $(P=0.005)$ : nonv_05, 4.40; nonv_15, 4.97; vern_15, 4.43; nonv_16, 4.21. In all experiments, several QTLs exceeding $P=0.005$ threshold were identified. Corresponding QTL regions from at least two experiments without pre-sowing vernalization were overlapping for 5 loci. Namely, LOD peaks were localized in linkage groups ALB02 at $2.2 \mathrm{cM}$ (2 experiments) and 100.2/100.5 cM (3 experiments), ALB13 at 96.2/99.3 cM (3 experiments), ALB16 at 0.9/2.2 cM (3 experiments), and ALB24 at 0.0/2.1 cM (2 experiments) (Table 3). Three loci (ALB02-100.2/ 100.5 cM, ALB13-96.2/99.3 cM, and ALB16-0.9/ $2.2 \mathrm{cM}$ ) were supported by LOD values higher than 10 in all three experiments. Three QTLs (ALB02$2.2 \mathrm{cM}$, ALB02-100.2/100.5 cM, and ALB13-96.2/ $99.3 \mathrm{cM}$ ) were revealed to be absolutely co-localized with GI-F1, FTa1-F1/FTa1-F2, and SEP3-F1 markers, respectively. The QTL at ALB16-0.9/ $2.2 \mathrm{cM}$ was revealed to be a few centimorgans upstream of FRI31-F1 marker. Such an observation highlighted GIGANTEA, FLOWERING LOCUS T, SEPALLATA 3, and FRIGIDA 3 as candidate genes underlying these QTLs in white lupin (Fig. 1). Moreover, one of the two major anthracnose resistance LOD peaks co-localized to early-flowering LOD peak at ALB02 locus $2.2 \mathrm{cM}$ and GI-F1 marker. The 
Table 2 Molecular markers anchored in white lupin homologs of genes involved in flowering induction and vernalization responsiveness

\begin{tabular}{|c|c|c|c|c|c|c|}
\hline Linkage group & Locus cM & LOD & Marker name & Polymorphism detection & Products Kiev Mutant (bp) & Products P27174 (bp) \\
\hline ALB01 & 42.2 & 44.7 & FY-F6 & CAPS, Tsp45I & 233,202 & 435 \\
\hline ALB02 & 2.2 & 54.5 & GI-F1 & dCAPS, AciI & 127,30 & 157 \\
\hline ALB02 & 100.2 & 56.6 & FTa1-F1 & Product length & 2036 & 1353 \\
\hline ALB02 & 100.2 & 56.6 & FTa1-F2 & Product length & 2218 & 1535 \\
\hline ALB03 & 62.8 & 41.6 & FLD-F1 & CAPS, AciI & $292,140,87,12$ & $292,94,87,46,12$ \\
\hline ALB04 & 7.3 & 54.2 & PIF4-F6 & CAPS, Hpy $188 \mathrm{III}$ & 138,52 & $102,52,36$ \\
\hline ALB04 & 7.6 & 54.2 & PIF4-F3 & CAPS, CvikI-1 & $\begin{array}{l}522,243,145,112,108 \\
\quad 76,66,47\end{array}$ & $\begin{array}{l}522,243,159,145, \\
108,76,66\end{array}$ \\
\hline ALB05 & 68.1 & 58.4 & MFT-FT3-F1 & Product length & 295 & 311 \\
\hline ALB05 & 68.1 & 58.4 & MFTa1-F1 & CAPS, AvaII & $1408,338,195,119,57$ & $\begin{array}{l}1425,338,195,119 \\
\quad 38,19\end{array}$ \\
\hline ALB07 & 1.4 & 47.3 & SPL6-F3 & CAPS, TaqI & 267,119 & 386 \\
\hline ALB07 & 12.2 & 49.4 & VIP3-F2 & CAPS, NlaIV & $114,85,70$ & 184,85 \\
\hline ALB07 & 15.3 & 47.3 & FCA-F3 & CAPS, RsaI & $822,503,148,106$ & $822,651,106$ \\
\hline ALB09 & 34.4 & 32.9 & SVP-F5 & CAPS, DdeI & 122,19 & $93,29,19$ \\
\hline ALB09 & 96.0 & 39.4 & FTc2-F4 & dCAPS, NlaIII & 147,22 & 169 \\
\hline ALB10 & 15.1 & 39.9 & CO-F1 & CAPS, $M n l I$ & $\begin{array}{l}161,159,65,59,58,34 \\
\quad 14,7,3\end{array}$ & $\begin{array}{l}161,159,123,59,34 \\
\quad 14,7,3\end{array}$ \\
\hline ALB11 & 37.8 & 46.5 & FRI-F1 & CAPS, SfaNI & $347,242,227$ & 574,242 \\
\hline ALB13 & 74.2 & 33.5 & SKIP1-F2 & dCAPS, BseDI & 79 & 48,31 \\
\hline ALB13 & 99.3 & 51.5 & SEP3-F1 & dCAPS, TaqI & 122,23 & 145 \\
\hline ALB14 & 53.9 & 36 & FTc1-F4 & Product length & 298 & 291 \\
\hline ALB16 & 5.8 & 32.4 & FRI31-F1 & CAPS, MseI & 254 & 179,75 \\
\hline ALB18 & 31.5 & 45.2 & LD-F1 & CAPS, $M n l \mathrm{I}$ & $967,185,82,18$ & $1152,82,18$ \\
\hline ALB18 & 71.6 & 58.7 & ESD4-F7 & dCAPS, EcoRV & 232,22 & 254 \\
\hline ALB18 & 71.6 & 58.7 & ESD4-F8 & CAPS, MseI & 351 & 178,173 \\
\hline ALB20 & 24.4 & 58.1 & TFL1-FT4-F2 & Product length & 716 & 695 \\
\hline ALB20 & 24.4 & 58.1 & TFL1-FT6-F1 & Product length & 476 & 453 \\
\hline ALB20 & 64.5 & 46.1 & FKF-F2M & CAPS, ClaI & 525 & 310,215 \\
\hline ALB21 & 91.4 & 39.3 & ELF1-F1 & CAPS, AciI & 1160,282 & 1442 \\
\hline ALB22 & 35.5 & 47.3 & ELF3-F1 & CAPS, AciI & $239,131,120,12$ & 382,120 \\
\hline ALB24 & 25.9 & 48.2 & FPA-F5 & CAPS, TaaI & 363,110 & 473 \\
\hline - & - & - & ELF4-F1 & CAPS, DdeI & 205,83 & $205,54,29$ \\
\hline - & - & - & PIF4-F1 & CAPS, $M n l I$ & $458,364,7,4$ & $392,364,66,7,4$ \\
\hline- & - & - & SPL6-F1 & CAPS, TaqI & 742,119 & 861 \\
\hline- & - & - & SPL6-F2 & CAPS, TaqI & 261,119 & 380 \\
\hline
\end{tabular}

experiment based on vernalized plants revealed the existence of three weak QTLs (LOD values below 10) located in different regions than the QTLs found in experiments with non-vernalized plants. Such an observation is an expected outcome because lateflowering parent is highly vernalization responsive, whereas early-flowering parent is almost thermoneutral. Moreover, this result suggests that the major genes accelerating plant flowering in nonvernalized experiments were those involved in the vernalization pathway. LOD, proportion of phenotypic explained variance, and additive effect values for 
analyzed white lupin quantitative traits are provided in Supplementary Table 11.

To address the putative involvement of other cisacting factors, synteny-based approach has been adopted. White lupin linkage map was aligned to the narrow-leafed lupin genome assembly, and then, regions highly syntenic to white lupin QTLs were mined for the presence of hypothetical homologs of flowering induction pathway genes (Fig. 2). Results of the alignment are provided in Supplementary Table 12.

The first QTL from the white lupin linkage group ALB02 region $0.0-8.6 \mathrm{cM}$ revealed direct collinearity to the narrow-leafed lupin chromosome NLL20 region $0.0-1.38 \mathrm{Mb}$. Only two potential flowering induction genes were found here, AGAMOUS 42 (AGL42, Lup002088) and GI (Lup002034). Moreover, L. angustifolius GI position matched perfectly $L$. albus GI-F1 marker and LOD peak locus, whereas AGL42 syntenic locus was found $\sim 2.1 \mathrm{cM}$ above the QTL. Other homologs in the proximal chromosome region were as follows: GIBBERELIN REGULATED PROTEIN (GASA, LUP030346), SQUAMOSA PROMOTER BINDING PROTEIN 6 (SPL6, Lup016987), PIF3 (Lup017000 and Lup017026), PHYA (Lup017016), AGL38 (Lup017030), and AGL80 (Lup015610). These genes were located $\sim 2-5 \mathrm{Mb}$ or $\sim 15-25 \mathrm{cM}$ from the QTL.

The second QTL region from the white lupin linkage group ALB02 $(96.2-102.6 \mathrm{cM})$ showed high synteny to the narrow-leafed lupin chromosome NLL20 region 21.1-21.9 Mb. The only known flowering induction regulatory gene localized here was the $F T$ homolog, LanFTa1 (Lup021189). The position of this gene corresponded perfectly to the LOD peak of this QTL and a pair of FTa1-F1/ FTa1-F2 markers. Other genes located in the chromosomal proximity were $A G L 8$ (Lup001398), SEP2 (Lup001397), and SKIP (Lup001577); however, due to high recombination rate in this region, their physical positions in the $L$. angustifolius genome addressed L. albus linkage map loci localized several centimorgans away from the QTL peak.

The QTL region from the white lupin linkage group ALB13 (98.8-100.7 cM) revealed conserved synteny to the narrow-leafed lupin chromosome NLL01 (0.2$1.2 \mathrm{Mb})$. Several flowering induction regulatory genes have been found here, including FPF1 (Lup018401), AGL65 (Lup018444), SQUAMOSA (SQA, Lup018483), SEP4 (Lup018484), and AGL8
(Lup018485). These genes were revealed to form a cluster in the L. angustifolius genome matching directly the position of L. albus SEP3-F1 marker and the QTL peak. Therefore, explicit identification of a gene underlying this QTL requires omics-based approach. Currently, SEP3 is the strongest candidate confirmed by linkage mapping. Some APETALA2 (AP2, Lup009441) and VRN5 (Lup009440) copies were annotated at a $2.8 \mathrm{Mb}$ physical distance but this region had L. albus collinearity landmarks mapped about $25-30 \mathrm{cM}$ away from the QTL peak.

The QTL region from the white lupin linkage group ALB16 (0.0-4.7 cM) showed synteny to the narrowleafed lupin chromosome NLL01 (15.0-16.6 Mb). Only FRI3 (Lup000989) was annotated here as a putative flowering induction regulator. The position of this gene matched the locus FRI31-F1, which is located $3.6 \mathrm{cM}$ away from the LOD peak indicating the possibility of the contribution of different cis-acting factor. However, other genes from flowering regulation pathways found in this chromosome region, namely AP2 (Lup020693), AGL21 (Lup020683), and SKIP (Lup020580), had syntenic loci located as far as $\sim 12-20 \mathrm{cM}$ away from the QTL peak. Therefore, the FRI3 gene has been proposed as a candidate gene for this QTL.

The QTL region from the white lupin linkage group ALB24 $(0.0-2.1 \mathrm{cM})$ showed synteny to the narrowleafed lupin chromosome NLL06 ( 30.1 Mb). The putative homolog of $A$. thaliana At5g10150, UPSTREAM OF FLC gene, UFC, has been annotated here (Lup011259). Other closely localized genes include MYB transcription factor and histone family proteins.

The coordinates of candidate genes found in the narrow-leafed lupin genome regions syntenic to white lupin QTLs of flowering time are provided in Supplementary Table 13. Polymorphic marker data and matching white lupin transcriptome and narrow-leafed lupin protein sequences are provided in Supplementary Table 14.

\section{Discussion}

Accurate timing of flowering is crucial for the reproductive success of a plant. Triggering of inflorescence meristem requires gathering information from several pathways related to aging, photoperiod, and vernalization (Baurle and Dean 2006). Moreover, flowering can be also initiated in non-inductive conditions via gibberellin 
Table 3 Flowering time QTLs detected in a recombinant inbred line population of white lupin in field (nonv_05, nonv_15) and greenhouse (nonv_16) experiments without pre-sowing vernalization and in field (vern_15) experiment with vernalization applied

\begin{tabular}{|c|c|c|c|c|c|c|c|c|}
\hline $\begin{array}{l}\text { Linkage } \\
\text { group }\end{array}$ & Experiment & $\begin{array}{l}\text { Position } \\
\text { L O D } \\
-2.0 \\
\text { above } \\
\text { (cM) }\end{array}$ & $\begin{array}{l}\text { Position } \\
\text { LOD - } 1.0 \\
\text { above } \\
(\mathrm{cM})\end{array}$ & $\begin{array}{l}\text { Peak } \\
\text { position }(\mathrm{cM})\end{array}$ & $\begin{array}{l}\text { Position } \\
\text { LOD - } 1.0 \\
\text { below } \\
(\mathrm{cM})\end{array}$ & $\begin{array}{l}\text { Position } \\
\text { LOD - } 2.0 \\
\text { below } \\
(\mathrm{cM})\end{array}$ & PVE & $\begin{array}{l}\text { Peak } \\
\text { LOD value }\end{array}$ \\
\hline ALB01 & nonv_05 & 165.6 & 167.8 & 168.9 & 169.5 & 170.0 & 3.9 & 6.4 \\
\hline ALB02 & nonv_05 & 0.0 & 1.0 & 2.2 & 2.9 & 3.5 & 4.0 & 7.5 \\
\hline ALB02 & nonv_05 & 96.2 & 97.5 & 100.2 & 101.9 & 102.6 & 14.4 & 21.8 \\
\hline ALB13 & nonv_05 & 98.8 & 99.1 & 99.3 & 100.1 & 100.7 & 15.0 & 21.3 \\
\hline ALB16 & nonv_05 & 0.6 & 1.3 & 2.2 & 4.1 & 4.7 & 6.4 & 10.7 \\
\hline ALB01 & nonv_15 & 109.7 & 113.2 & 115.3 & 116.3 & 116.4 & 6.9 & 6.8 \\
\hline ALB01 & nonv_15 & 130.9 & 130.9 & 131.0 & 135.0 & 139.4 & 6.9 & 7.3 \\
\hline ALB02 & nonv_15 & 98.1 & 99.3 & 100.5 & 102.3 & 103.1 & 10.9 & 13.4 \\
\hline ALB04 & nonv_15 & 105.0 & 111.2 & 112.1 & 114.7 & 115.6 & 6.3 & 4.5 \\
\hline ALB13 & nonv_15 & 93.8 & 94.6 & 96.2 & 97.0 & 99.8 & 14.5 & 17.3 \\
\hline ALB16 & nonv_15 & 0.0 & 0.0 & 0.9 & 1.7 & 2.1 & 14.8 & 17.6 \\
\hline ALB24 & nonv_15 & 0.0 & 0.0 & 0.0 & 2.8 & 8.9 & 4.7 & 6.0 \\
\hline ALB02 & nonv_16 & 0.0 & 0.3 & 2.2 & 5.2 & 8.6 & 2.4 & 5.0 \\
\hline ALB02 & nonv_16 & 98.3 & 99.6 & 100.5 & 101.6 & 102.2 & 15.0 & 24.3 \\
\hline ALB13 & nonv_16 & 98.9 & 99.1 & 99.3 & 99.6 & 100.0 & 12.9 & 21.7 \\
\hline ALB16 & nonv_16 & 0.0 & 0.4 & 2.2 & 3.4 & 4.4 & 6.3 & 11.9 \\
\hline ALB21 & nonv_16 & 3.0 & 4.2 & 8.1 & 11.7 & 13.2 & 3.0 & 5.7 \\
\hline ALB24 & nonv_16 & 0.0 & 0.0 & 2.1 & 3.2 & 9.10 & 3.0 & 6.0 \\
\hline ALB03 & vern_15 & 10.8 & 14.9 & 16.2 & 17.2 & 17.6 & 11.3 & 7.7 \\
\hline ALB07 & vern_15 & 79.2 & 80.0 & 81.5 & 81.6 & 81.8 & 10.4 & 5.8 \\
\hline ALB20 & vern_15 & 37.6 & 39.1 & 40.2 & 43.7 & 44.9 & 7.1 & 5.0 \\
\hline
\end{tabular}

PVE proportion of phenotypic variance explained by QTL

pathway (Khan et al. 2014). Numerous cross-talks between pathways exist, enabling multilateral control of flowering induction in response to various environmental cues (Pose et al. 2012). In the present study, we analyzed more than 70 homologs of flowering induction genes, including all major regulatory pathways.

One of the most important abiotic factors affecting floral transition is photoperiod. Key elements responsible for light detection in plants are phytochromes (PHYA to PHYE) and cryptochromes (CRY1 and $C R Y 2$ ), sensing red/far-red and blue wavelengths, respectively (Toth et al. 2001). Light signal is later transduced via circadian clock-controlled pathway comprising the genes GIGANTEA (GI), CONSTANS (CO), and FLOWERING LOCUS T (FT) (Mizoguchi et al. 2005). FT protein works as a long distance mediator, targeting, with the meristem-specific bZIP transcription factor $F D$, floral meristem identity genes, such as APETALA1 (AP1), LEAFY (LFY), FRUITFUL (FUL), CAULIFLOWER (CAL), and SEPALLATA (SEP) (Pose et al. 2012). CO protein activates $F T$ expression directly binding to $\mathrm{CO}$ responsive elements (CORE1 and CORE2) (Adrian et al. 2010). Long-day detection is based on tight balance between local maximum of $C O$ gene expression in late afternoon, $\mathrm{CO}$ protein liability in darkness, and $\mathrm{CO}$ stabilization by FLAVIN-BINDING KELCH REPEAT F-BOX 1 (FKF1) (Song et al. 2012; Valverde et al. 2004).

Transition from vegetative to generative phase may require prolonged exposition to low temperatures, a phenomenon known as vernalization. In Arabidopsis, vernalization response is based on two dominant genes, FRIGIDA (FRI) and FLOWERING LOCUS C (FLC) (Michaels and Amasino 1999). FLC is a MADS-box transcription factor acting as floral repressor by blocking 
a

\section{ALB02}

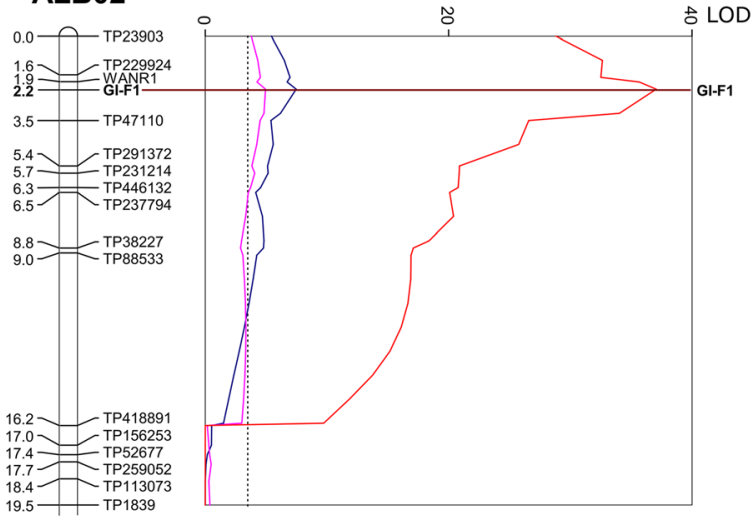

c

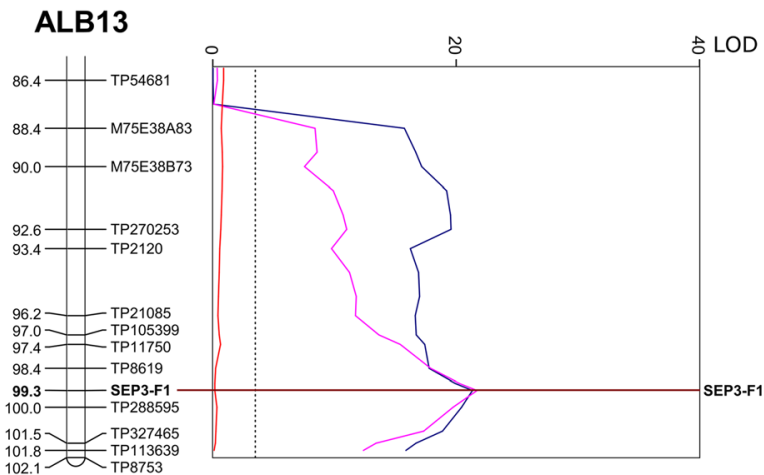

Fig. 1 Major QTLs for time to flowering in white lupin. Linear plots show LOD values (threshold 3.5) whereas vertical bar graphs visualize corresponding linkage group fragments. Names of markers tagging candidate genes are boldfaced. Colors corresponds to QTL data: blue, "nonv 05," time to flowering from field experiments performed in Perth, Western Australia in years

transcriptional activation via interacting with $\mathrm{CArG}$ sequences of $F T$ and SUPPRESSOR OF OVEREXPRESSION OF CONSTANS 1 (SOC1) (Helliwell et al. 2006). FRI also suppress flowering, by increasing the expression level of $F L C$, as well as through other mechanisms (Michaels and Amasino 2001). However, FLC clade appears to be lacking in galegoid legumes, including lupins (Weller and Ortega 2015; Hane et al. 2017).

Other genes involved in vernalization pathway are SHORT VEGETATIVE PHASE (SVP), b

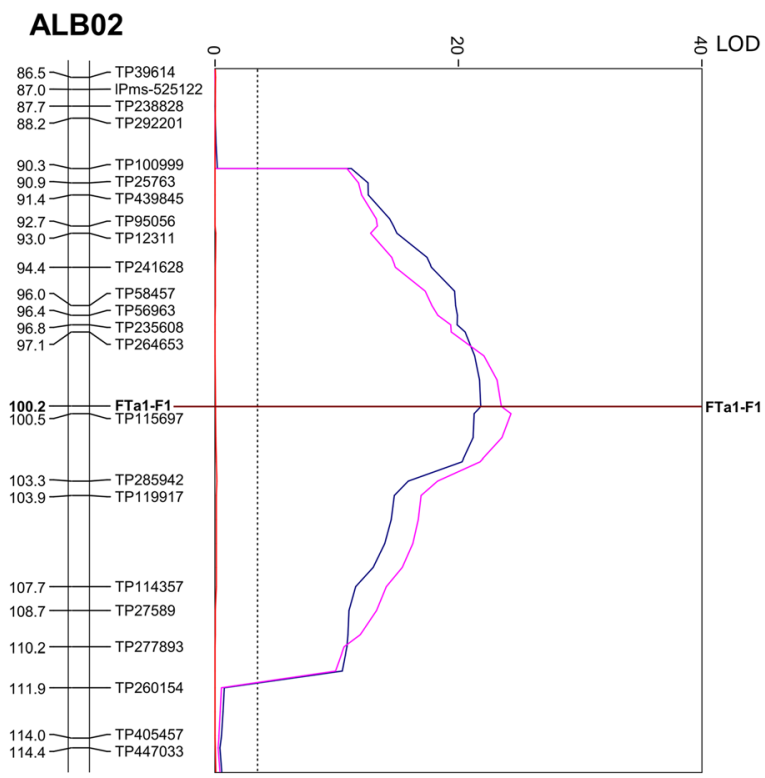

d

\section{ALB16}

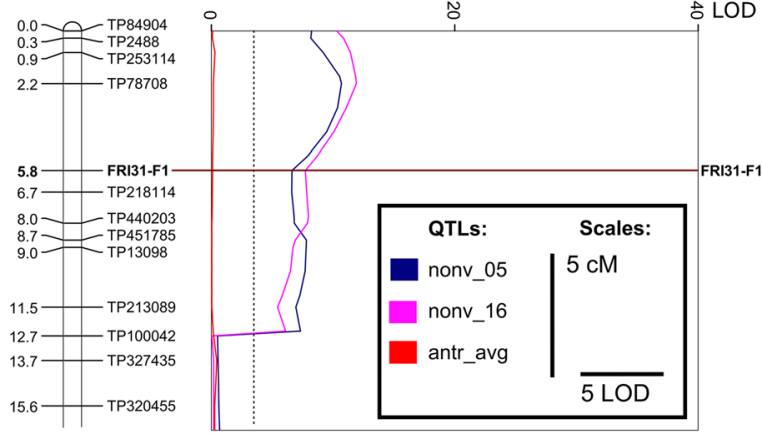

2004 and 2005 ( $n=190)$; pink, "nonv_16," time to flowering from greenhouse experiment performed in Poznań, Poland in year 2016 $(n=192)$; red, "antr_avg," anthracnose resistance screening performed in Perth, Western Australia in years 2004 and 2005 ( $n=$ 191). Linkage groups and LOD graphs are drawn to scale

VERNALIZATION INSENSITIVE 3 (VIN3), VERNALIZATION 1 (VRN1), and VRN2. SVP physically interacts with FLC and repress flowering by direct binding to the CArG motifs in the FT sequence (Lee et al. 2007). Loss of function $S V P$ mutation results in early-flowering Arabidopsis phenotype (Mendez-Vigo et al. 2013). VIN3 is a chromatin remodeling plant homeodomain finger protein that contributes to the establishment of vernalized state (Sung and Amasino 2004; Bond et al. 2009). VRN1 repress the major regulator of 


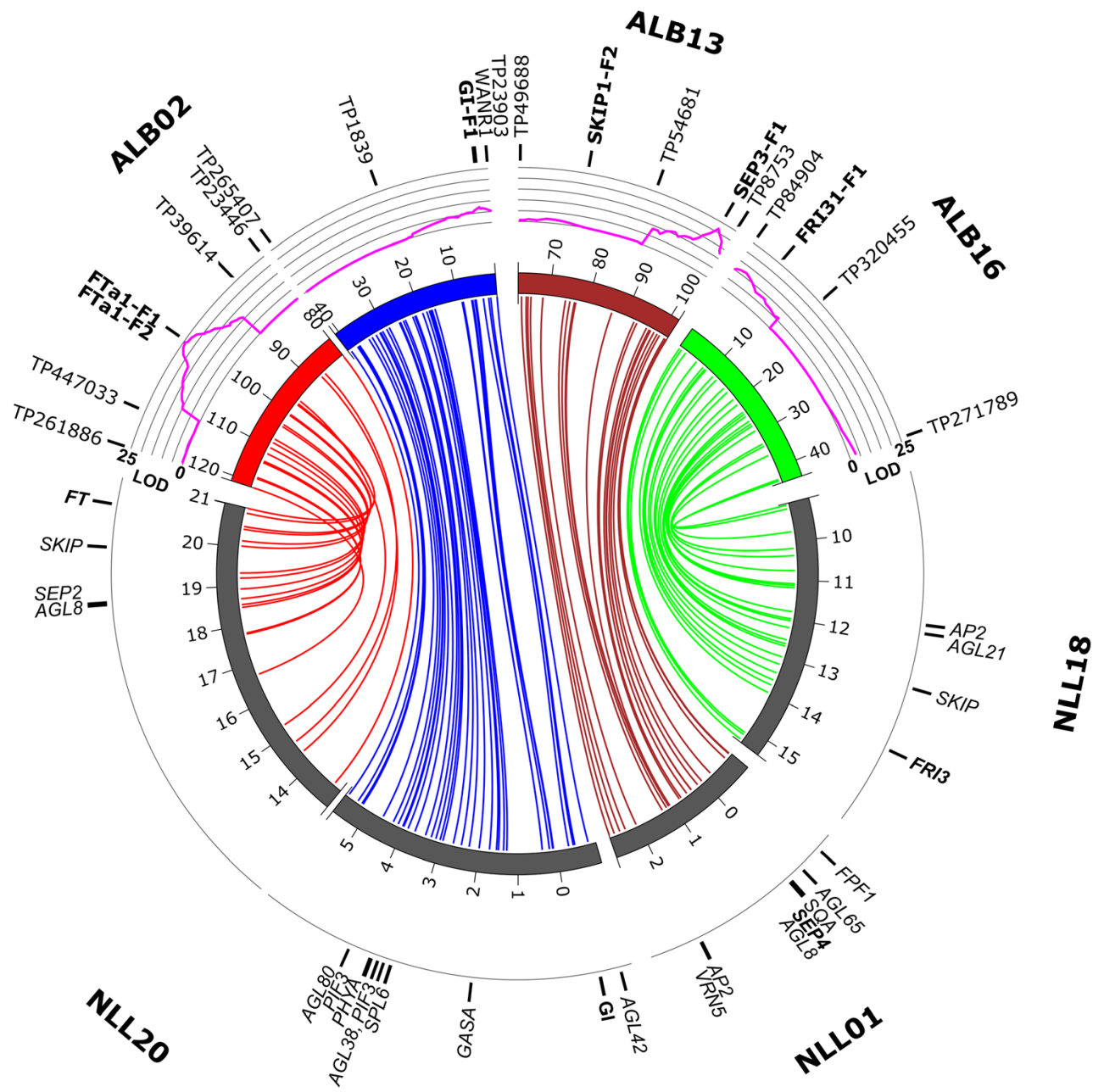

Fig. 2 Collinearity links matching white lupin (ALB02, ALB13, and ALB16) linkage groups and narrow-leafed lupin (NLL-01, NLL-18, NLL-20) pseudochromosomes in the regions carrying QTL loci of time to flowering. Ribbons symbolize homologous links identified by DNA sequence similarity. Ribbon colors red, blue, brown, and green corresponds to regions on white lupin linkage groups. Tick values provide genetic (linkage groups, cM)

vernalization pathway, the floral repressor FLC. Overexpression of $V R N 1$ results in vernalization-independent phenotype, conferred predominantly through the floral pathway integrator FT (Levy et al. 2002). VRN2 encodes a nuclear-localized zinc finger protein of Polycomb group and acts by maintaining FLC repression after a cold treatment (Gendall et al. 2001). VERNALIZATION INDEPENDENCE 4 (VIP4) confer early flowering and loss of FLC expression in the absence of cold, however, putatively regulates flowering-time genes in addition to FLC (Zhang and van Nocker 2002). Cold-independent flowering and suppression of and physical (chromosomes, Mb) distances. Circular graphs (magenta) show LOD values calculated for time to flowering from greenhouse experiment performed in Poznań, Poland in year 2016 $(n=192)$. Labels localized outside the ideogram circle indicate markers (on linkage groups) and flowering time pathway regulatory genes (on chromosomes). Chromosomes and linkage groups are not drawn to scale

FLC have also been observed in VIP3 mutants (Zhang et al. 2003)

Flowering induction is also regulated by autonomous pathway. Genes involved in this mechanism were discovered by studies of late-flowering, photoperiod-independent, vernalization-responsive mutants (Khan et al. 2014). Numerous genes contributing to autonomous pathway were identified, including LUMINIDEPENDENS (LD), FLOWERING CONTROL LOCUS A (FCA), FLOWERING LOCUS D (FLD), FLOWERING LOCUS K (FLK), FLOWERING PROTEIN A (FPA), FY, FVE, and RELATIVE OF EARLY 
FLOWERING 6 (REF6) (Simpson 2004; Noh et al. 2004). Two major mechanisms are harnessed in autonomous pathway of flowering control: RNA regulatory processes, carried by FCA, FPA, FY, and FLK, or chromatin modification state regulation, related to $L D, F V E$, FLD, and REF6 (Noh et al. 2004; He 2012; Simpson 2004; Kim and Sung 2014).

Gibberellic acid (GA), a plant hormone stimulating plant growth and development, also promotes flowering in model plants. Indeed, mutations in gibberellinresponsive genes influence juvenile-to-adult phase transition and flowering induction. These genes include $B O$ TRYTIS SUSCEPTIBLE1 INTERACTOR (BOI), BOIRELATED GENE1 (BRG1), BRG2, BRG3, SPINDLY (SPY), SOC1, and AGAMOUS LIKE 24 (AGL24) (Moon et al. 2003; Park et al. 2013; Jacobsen et al. 1996).

The key control point where numerous pathways converge is the transcriptional regulation of FT gene (Liu et al. 2014). FT is a member of phosphatidylethanolamine-binding protein (PEBP) family, an ancient group of proteins (Hengst et al. 2001; Banfield et al. 1998). In plants, four subfamilies of PEBP were revealed: FT-like, BFT-like, TFL1-like, and MOTHER OF FT AND TFL1 (MFT)-like (Danilevskaya et al. 2008). Whole genome duplications considerably contributed to the expansion of PEBP family in legumes, resulting in a relatively high number of retained homologs, especially in FT-like and TFL1like subclades (Książkiewicz et al. 2016). Therefore, $F T$-like genes were grouped into three subclades FTa, $F T b$, and $F T c$ in legumes. $F T$ promoter and introns contain elements that alter $F T$ expression in response to photoperiod and vernalization, and consequently, induce flowering (Andres and Coupland 2012).

The present study provided the FTal homolog as a candidate gene for one of the two most important QTLs of early flowering in white lupin (linkage group ALB02, locus $100.2 \mathrm{cM}$ ), whereas in the sister lupin crop species, narrow-leafed lupin, this trait is conferred by the FTc1 homolog (Nelson et al. 2017). Such an observation is not unexpected, as the involvement of FTal gene in flowering time regulation is a common phenomenon in legumes. In M. truncatula L., FTal gene confers vernalization responsiveness and early flowering, whereas $F T b$ contributes to the photoperiod pathway (Laurie et al. 2011; Hecht et al. 2011). In G. $\max$, a vernalization-independent species, three genes classified as FTa and FTc maintain the photoperiod response (Kong et al. 2010; Hecht et al. 2011; Laurie et al. 2011;
Takeshima et al. 2016). In pea, FT genes have distinctly different expression patterns across plant development stages, tissue specificity, and response to photoperiod. FTal gene corresponds to the pea GIGAS locus, which is essential for flowering under long-day conditions and promotes flowering under short-day conditions (Hecht et al. 2011). All these findings support the hypothesis on the contribution of the FTal homolog to early-flowering phenotype in white lupin.

GI homolog was identified here as a putative gene underlying early-flowering QTL in white lupin located in linkage group ALB02 at $2.2 \mathrm{cM}$ locus. Study involving a model plant $A$. thaliana highlighted that GI participates in circadian clock regulation and long day-induced flowering (Kim et al. 2012). Similar functions were also revealed for this gene in pea (Hecht et al. 2007). GI was also evidenced by map-based cloning strategy to be a gene underlying e2 early-flowering genotype in soybean (Watanabe et al. 2011). Our research revealed also colocalization of GI-F1 marker and a major anthracnose resistance QTL in white lupin. This result may indicate that GI gene has multiple roles in white lupin. Recently confirmed functions included escape-based drought tolerance and increased susceptibility to pathogenic fungi (Lyons et al. 2015; LaFlamme 2015). Combining of early flowering with anthracnose resistance in white lupin was fairly ineffective when a Kiev Mutant was used as an early-flowering donor; however, it was much more productive when a different source of early flowering was used (Adhikari et al. 2009; Adhikari et al. 2013). These observations justify the concept on the parallel contribution of white lupin GI homo$\log$ to early flowering and anthracnose susceptibility.

SEP3-F1 marker was found to co-localize with the most influential early-flowering QTL in white lupin, located at ALB13. However, in the region of the narrow-leafed lupin genome highly syntenic to this locus, a cluster of several flowering induction regulatory genes has been found, including FPF1, SQA, SEP4, and $A G L 8$. FPF1 has not been found in the transcriptome of vernalized P27174 and Kiev Mutant lines; therefore, it is putatively not involved in the flowering initiation process. However, other genes were present in the RNAseq assemblies and may contribute to this trait. The resolution of linkage mapping is too low to make firm conclusions on SEP3 homolog contribution to white lupin early-flowering trait. 
FRI3-F1 marker has been mapped in a locus adjacent to the early-flowering QTL peak in white lupin linkage group ALB16, at a distance of $3.6 \mathrm{cM}$. Despite the lack of any other marker separating these two loci, observed decrease of LOD calculated for the QTL indicates the hypothetical involvement of other cis-acting gene. However, only FRI homolog was found in the syntenic region of the narrow-leafed lupin assembly as a putative flowering induction regulatory gene. As the whole FLC clade is lacking, FRI genes may be considered as major vernalization pathway compounds in lupins. Indeed, allelic variation of FRI accounts for approximately $70 \%$ of flowering time variation in A. thaliana germplasm collection (Shindo et al. 2005). Moreover, modulation of flowering time in A. thaliana in response to vernalization is maintained by proteasome-mediated degradation of FRI protein (Hu et al. 2014).

$U F C$ gene is the major candidate for the earlyflowering QTL locus in white lupin linkage group ALB24. In Arabidopsis, the repression of UFC by vernalization pathway occurs independently of the endogenous FLC gene and does not involve VIN3 and VRN2 components of a PRC2-like complex required for FLC repression (Sheldon et al. 2009).

Hypothetical involvement of white lupin homologs of GI, FTa1, SEP3, FRI3, and UFC genes in early flowering and vernalization responsiveness could be evidenced by transcriptome-based study involving P27174, Kiev Mutant, and selected RILs differing by time to flowering. However, such research has been hampered by very limited germplasm resources and high vernalization requirement of Ethiopian parent. Recently, attempts have been undertaken to multiply seeds of RIL population by 21-day vernalization $\left(5^{\circ} \mathrm{C}\right)$ and subsequent plant cultivation for 8 months in control environment chamber with $16 \mathrm{~h}$ photoperiod and temperature regime of $18-22{ }^{\circ} \mathrm{C}$. For some late-flowering RILs and P27174, negligible seed yields were observed, indicating the need of longer vernalization period to ensure full flowering.

The study reinforced the need of the introduction of untapped early-flowering accessions to breeding programs. Such landraces with higher yielding ability than current cultivars are available in world germplasm collection for further exploitation (Annicchiarico et al. 2010). Some landraces were also shown to out-yield domesticated germplasm under drought stress conditions due to escape by advanced flowering (Annicchiarico et al. 2018). There is also a considerable number of Ethiopian white lupin accessions to be harnessed by breeders; however, their genetic diversity is limited (Raman et al. 2014). Thus, a core collection of 34 lines represent $\sim 100 \%$ of molecular marker diversity found in 212 Ethiopian germplasm accessions (Atnaf et al. 2017). It was well evidenced for the sister crop species, narrow-leafed lupin, that domestication bottlenecks considerably limited genetic diversity and constrained adaptation of Australian improved germplasm to diverse environmental conditions, including vernalization requirement (Berger et al. 2012). To address this issue, a model for incorporating novel narrowleafed lupin alleles from primary gene pool into elite breeding programs while reselecting major domestication genes was established (Cowling et al. 2009). However, due to different control of early flowering and anthracnose resistance in L. albus compared with L. angustifolius, in the form of different number of genes involved (several QTLs vs single genes) and different inheritance patterns (recessive vs dominant), this model cannot be directly translated to white lupin (Książkiewicz et al. 2017). Molecular markers targeting candidate genes developed in the present study should have facilitated the issue of tracking late-flowering alleles in further white lupin breeding approaches involving primitive Ethiopian germplasm.

Acknowledgments We thank the Department of Agriculture and Food of Western Australia (Perth, Australia) for the seeds of Kiev Mutant $\times$ P27174 mapping population. We thank Poznan Plant Breeding Ltd. station located in Wiatrowo for the seeds of white lupin lines for vernalization assay. We also thank Dr. Matthew Nelson for pre-publication access to the white lupin transcriptome data (SRX2663946 and SRX2663947).

Author's contribution SR performed transcriptome and genome sequence alignments, designed molecular markers and confirmed them by direct sequencing, isolated DNA from mapping population, and performed all laboratory work required to obtain marker segregation data. MK contributed partially to marker design and performed annotation of gene sequences, CDS prediction, comparative mapping, linkage, and QTL mapping as well as prepared figures and drafted a manuscript. MT performed the assay of white lupin vernalization responsiveness in controlled environment. WB handled submission of marker sequences. BW contributed to the concept of the study and experiment design.

Funding The study obtained financial support from Polish Ministry of Agriculture and Rural Development under Task No. 39 of Basic Research for Biological Progress in Crop Production program.Data availability All data generated and analyzed in the study are included in this published article and its supplementary information files. Kiev Mutant and P27174 RNAseq data are available under Sequence Read Archive accession numbers 
SRX2663946 and SRX2663947. Marker sequences were deposited in the DNA Data Bank of Japan (accession numbers LC434127- LC434318).

\section{Compliance with ethical standards}

Conflict of interest The authors declare that they have no conflict of interest.

Open Access This article is distributed under the terms of the Creative Commons Attribution 4.0 International License (http:// creativecommons.org/licenses/by/4.0/), which permits unrestricted use, distribution, and reproduction in any medium, provided you give appropriate credit to the original author(s) and the source, provide a link to the Creative Commons license, and indicate if changes were made.

Publisher's note Springer Nature remains neutral with regard to jurisdictional claims in published maps and institutional affiliations.

\section{References}

Adhikari KN, Buirchell BJ, Thomas GJ, Sweetingham MW, Yang H (2009) Identification of anthracnose resistance in Lupinus albus $\mathrm{L}$. and its transfer from landraces to modern cultivars. Crop Pasture Sci 60:472-479. https://doi.org/10.1071 /CP08092

Adhikari K, Buirchell B, Yan G, Sweetingham M (2011) Two complementary dominant genes control flowering time in albus lupin (Lupinus albus L.). Plant Breed 130(4):496499. https://doi.org/10.1111/j.1439-0523.2011.01858.x

Adhikari KN, Buirchell BJ, Sweetingham MW (2012) Length of vernalization period affects flowering time in three lupin species. Plant Breed 131(5):631-636. https://doi. org/10.1111/j.1439-0523.2012.01996.x

Adhikari KN, Thomas G, Diepeveen D, Trethowan R (2013) Overcoming the barriers of combining early flowering and anthracnose resistance in white lupin (Lupinus albus L.) for the northern agricultural region of Western Australia. Crop Pasture Sci 64(9):914-921. https://doi.org/10.1071/CP13249

Adrian J, Farrona S, Reimer JJ, Albani MC, Coupland G, Turck F (2010) Cis-regulatory elements and chromatin state coordinately control temporal and spatial expression of FLOWERING LOCUS T in Arabidopsis. Plant Cell 22(5): 1425-1440. https://doi.org/10.1105/tpc.110.074682

Altschul SF, Gish W, Miller W, Myers EW, Lipman DJ (1990) Basic local alignment search tool. J Mol Biol 215:403-410. https://doi.org/10.1016/S0022-2836(05)80360-2

Andres F, Coupland G (2012) The genetic basis of flowering responses to seasonal cues. Nat Rev Genet 13(9):627-639. https://doi.org/10.1038/nrg3291

Annicchiarico P, Harzic N, Carroni AM (2010) Adaptation, diversity, and exploitation of global white lupin (Lupinus albus L.) landrace genetic resources. Field Crops Res 119(1):114-124. https://doi.org/10.1016/j.fcr.2010.06.022
Annicchiarico P, Romani M, Pecetti L (2018) White lupin (Lupinus albus) variation for adaptation to severe drought stress. Plant Breed. https://doi.org/10.1111/pbr.12642

Atnaf M, Yao N, Martina K, Dagne K, Wegary D, Tesfaye K (2017) Molecular genetic diversity and population structure of Ethiopian white lupin landraces: implications for breeding and conservation. PLoS One 12(11):e0188696. https://doi. org/10.1371/journal.pone.0188696

Banfield MJ, Barker JJ, Perry AC, Brady RL (1998) Function from structure? The crystal structure of human phosphatidylethanolamine-binding protein suggests a role in membrane signal transduction. Structure 6(10):12451254. https://doi.org/10.1016/S0969-2126(98)00125-7

Baurle I, Dean C (2006) The timing of developmental transitions in plants. Cell 125(4):655-664. https://doi.org/10.1016/j. cell.2006.05.005

Berger JD, Buirchell BJ, Luckett DJ, Nelson MN (2012) Domestication bottlenecks limit genetic diversity and constrain adaptation in narrow-leafed lupin (Lupinus angustifolius L.). Theor Appl Genet 124(4):637-652. https://doi.org/10.1007/s00122-011-1736-Z

Boersma JG, Buirchell BJ, Sivasithamparam K, Yang H (2007) Development of a sequence-specific PCR marker linked to the $K u$ gene which removes the vernalization requirement in narrow-leafed lupin. Plant Breed 126:306-309. https://doi. org/10.1111/j.1439-0523.2007.01347.x

Bond DM, Dennis ES, Pogson BJ, Finnegan EJ (2009) Histone acetylation, VERNALIZATION INSENSITIVE 3, FLOWERING LOCUS $C$, and the vernalization response. Mol Plant 2(4):724-737. https://doi.org/10.1093/mp/ssp021

Cowling WA, Buirchell BJ, Falk DE (2009) A model for incorporating novel alleles from the primary gene pool into elite crop breeding programs while reselecting major genes for domestication or adaptation. Crop Pasture Sci 60(10):1009-1015. https://doi.org/10.1071/CP08223

Croxford AE, Rogers T, Caligari PDS, Wilkinson MJ (2008) High-resolution melt analysis to identify and map sequence-tagged site anchor points onto linkage maps: a white lupin (Lupinus albus) map as an exemplar. New Phytol 180:594-607. https://doi.org/10.1111/j.14698137.2008.02588.x

Danilevskaya ON, Meng X, Hou Z, Ananiev EV, Simmons CR (2008) A genomic and expression compendium of the expanded PEBP gene family from maize. Plant Physiol 146(1): 250-264. https://doi.org/10.1104/pp.107.109538

Darling AC, Mau B, Blattner FR, Perna NT (2004) Mauve: multiple alignment of conserved genomic sequence with rearrangements. Genome Res 14(7):1394-1403. https://doi. org/10.1101/gr.2289704

Edgar RC (2004) MUSCLE: multiple sequence alignment with high accuracy and high throughput. Nucleic Acids Res 32: 1792-1797. https://doi.org/10.1093/nar/gkh340

Gendall AR, Levy YY, Wilson A, Dean C (2001) The VERNALIZATION 2 gene mediates the epigenetic regulation of vernalization in Arabidopsis. Cell 107(4):525-535. https://doi.org/10.1016/S0092-8674(01)00573-6

Gladstones J, Hill G (1969) Selection for economic characters in Lupinus angustifolius and $L$. digitatus. 2. Time of flowering. Aust J Exp Agric 9(37):213-220. https://doi.org/10.1071 /EA9690213 
Gladstones JS, Atkins CA, Hamblin J (1998) Lupins as crop plants: biology, production, and utilization. CAB International, New York

Gondran J, Bateman GL, Milford GFJ, Bayer J, Beerepoot L, Boller B, Caligari PDS, Carrasco-Lopez JM, Crowley JG, da Rocha JJP, Feiler U, Gataulina GG, Golovchenko OV, Korneichuk NS, Frencel I, Jaubertie JP, Jeffes M, Jordan AC, Jörnsgaard B, Neves-Martins JM, Mackinaite R, Postiglione L, Reheul D, Römer P, Schrems H, Szukala J, TelloMarquina JC (1996) Anthracnose of white lupin (Lupinus albus): European prospects for a future sustainable crop. Proceedings of the 8th International Lupin Conference, May 11-16, 1996, Asilomar, USA. 8th International Lupin Conference. International Lupin Association, Asilomar

Hane JK, Ming Y, Kamphuis LG, Nelson MN, Garg G, Atkins CA, Bayer PE, Bravo A, Bringans S, Cannon S, Edwards D, Foley R, Gao LL, Harrison MJ, Huang W, Hurgobin B, Li S, Liu CW, McGrath A, Morahan G, Murray J, Weller J, Jian J, Singh KB (2017) A comprehensive draft genome sequence for lupin (Lupinus angustifolius), an emerging health food: insights into plant-microbe interactions and legume evolution. Plant Biotechnol J 15(3):318-330. https://doi. org/10.1111/pbi.12615

He Y (2012) Chromatin regulation of flowering. Trends Plant Sci 17 (9):556-562.https://doi.org/10.1016/j. tplants.2012.05.001

Hecht V, Knowles CL, Vander Schoor JK, Liew LC, Jones SE, Lambert MJM, Weller JL (2007) Pea LATE BLOOMER1 is a GIGANTEA ortholog with roles in photoperiodic flowering, deetiolation, and transcriptional regulation of circadian clock gene homologs. Plant Physiol 144(2):648-661. https://doi. org/10.1104/pp.107.096818

Hecht V, Laurie RE, Vander Schoor JK, Ridge S, Knowles CL, Liew LC, Sussmilch FC, Murfet IC, Macknight RC, Weller JL (2011) The pea GIGAS gene is a FLOWERING LOCUS T homolog necessary for graft-transmissible specification of flowering but not for responsiveness to photoperiod. Plant Cell 23(1):147-161. https://doi.org/10.1105/tpc.110.081042

Helliwell CA, Wood CC, Robertson M, James Peacock W, Dennis ES (2006) The Arabidopsis FLC protein interacts directly in vivo with SOC1 and FT chromatin and is part of a highmolecular-weight protein complex. Plant J 46(2):183-192. https://doi.org/10.1111/j.1365-313X.2006.02686.x

Hengst U, Albrecht H, Hess D, Monard D (2001) The phosphatidylethanolamine-binding protein is the prototype of a novel family of serine protease inhibitors. J Biol Chem 276(1):535-540. https://doi.org/10.1074/jbc.M002524200

Hu X, Kong X, Wang C, Ma L, Zhao J, Wei J, Zhang X, Loake GJ, Zhang T, Huang J, Yang Y (2014) Proteasome-mediated degradation of FRIGIDA modulates flowering time in Arabidopsis during vernalization. Plant Cell 26(12):47634781. https://doi.org/10.1105/tpc. 114.132738

Huyghe C (1991) Winter growth of autumn-sown white lupin (Lupinus albus L.) main apex growth model. Ann Bot 67(4):429-434. https://doi.org/10.1093/oxfordjournals.aob. a088178

Jacobsen SE, Binkowski KA, Olszewski NE (1996) SPINDLY, a tetratricopeptide repeat protein involved in gibberellin signal transduction in Arabidopsis. Proc Natl Acad Sci U S A 93(17):9292-9296
Katoh K, Misawa K, Kuma K-i, Miyata T (2002) MAFFT: a novel method for rapid multiple sequence alignment based on fast Fourier transform. Nucleic Acids Res 30:3059-3066

Kearse M, Moir R, Wilson A, Stones-Havas S, Cheung M, Sturrock S, Buxton S, Cooper A, Markowitz S, Duran C, Thierer T, Ashton B, Meintjes P, Drummond A (2012) Geneious Basic: an integrated and extendable desktop software platform for the organization and analysis of sequence data. Bioinformatics 28:1647-1649. https://doi.org/10.1093 /bioinformatics/bts199

Khan MR, Ai XY, Zhang JZ (2014) Genetic regulation of flowering time in annual and perennial plants. Wiley Interdiscip Rev RNA 5(3):347-359. https://doi.org/10.1002 /wrna. 1215

Kim DH, Sung S (2014) Genetic and epigenetic mechanisms underlying vernalization. The Arabidopsis Book 12:e171. https://doi.org/10.1199/tab.0171

Kim Y, Yeom M, Kim H, Lim J, Koo HJ, Hwang D, Somers D, Nam HG (2012) GIGANTEA and EARLY FLOWERING 4 in Arabidopsis exhibit differential phase-specific genetic influences over a diurnal cycle. Mol Plant 5(3):678-687. https://doi.org/10.1093/mp/sss005

Kong F, Liu B, Xia Z, Sato S, Kim BM, Watanabe S, Yamada T, Tabata S, Kanazawa A, Harada K, Abe J (2010) Two coordinately regulated homologs of FLOWERING LOCUS T are involved in the control of photoperiodic flowering in soybean. Plant Physiol 154(3):1220-1231. https://doi. org/10.1104/pp.110.160796

Konieczny A, Ausubel FM (1993) A procedure for mapping Arabidopsis mutations using co-dominant ecotype-specific PCR-based markers. Plant J 4:403-410. https://doi. org/10.1046/j.1365-313X.1993.04020403.x

Kroc M, Rybiński W, Wilczura P, Kamel K, Kaczmarek Z, Barzyk P, Święcicki W (2017) Quantitative and qualitative analysis of alkaloids composition in the seeds of a white lupin (Lupinus albus L.) collection. Genet Resour Crop Evol 64(8):1853-1860. https://doi.org/10.1007/s10722-0160473-1

Krzywinski M, Schein J, Birol I, Connors J, Gascoyne R, Horsman D, Jones SJ, Marra MA (2009) Circos: an information aesthetic for comparative genomics. Genome Res 19: 1639-1645. https://doi.org/10.1101/gr.092759.109

Książkiewicz M, Rychel S, Nelson MN, Wyrwa K, Naganowska B, Wolko B (2016) Expansion of the phosphatidylethanolamine binding protein family in legumes: a case study of Lupinus angustifolius L. FLOWERING LOCUS T homologs, LanFTc1 and LanFTc2. BMC Genomics 17(1):820. https://doi.org/10.1186/s12864-016-3150-Z

Książkiewicz M, Nazzicari N, Yang H, Nelson MN, Renshaw D, Rychel S, Ferrari B, Carelli M, Tomaszewska M, Stawiński S, Naganowska B, Wolko B, Annicchiarico P (2017) A highdensity consensus linkage map of white lupin highlights synteny with narrow-leafed lupin and provides markers tagging key agronomic traits. Sci Rep 7:15335. https://doi. org/10.1038/s41598-017-15625-w

LaFlamme B (2015) The two sides of GIGANTEA. Nat Genet 47: 311-311. https://doi.org/10.1038/ng.3264

Laurie RE, Diwadkar P, Jaudal M, Zhang L, Hecht V, Wen J, Tadege M, Mysore KS, Putterill J, Weller JL, Macknight RC (2011) The Medicago FLOWERING LOCUS T homolog, 
MtFTa1, is a key regulator of flowering time. Plant Physiol 156(4):2207-2224. https://doi.org/10.1104/pp.111.180182

Lee JH, Yoo SJ, Park SH, Hwang I, Lee JS, Ahn JH (2007) Role of $S V P$ in the control of flowering time by ambient temperature in Arabidopsis. Genes Dev 21(4):397-402. https://doi. org/10.1101/gad.1518407

Levy YY, Mesnage S, Mylne JS, Gendall AR, Dean C (2002) Multiple roles of Arabidopsis VRN1 in vernalization and flowering time control. Science 297(5579):243-246. https://doi.org/10.1126/science.1072147

Liu L, Adrian J, Pankin A, Hu J, Dong X, von Korff M, Turck F (2014) Induced and natural variation of promoter length modulates the photoperiodic response of FLOWERING LOCUS T. Nat Commun 5:4558. https://doi.org/10.1038 /ncomms5558

Lyons R, Rusu A, Stiller J, Powell J, Manners JM, Kazan K (2015) Investigating the association between flowering time and defense in the Arabidopsis thaliana-Fusarium oxysporum interaction. PLoS One 10(6):e0127699. https://doi. org/10.1371/journal.pone.0127699

Manly KF, Robert H, Cudmore J, Meer JM (2001) Map manager QTX, cross-platform software for genetic mapping. Mamm Genome 12:930-932. https://doi.org/10.1007/s00335-0011016-3

Mendez-Vigo B, Martinez-Zapater JM, Alonso-Blanco C (2013) The flowering repressor SVP underlies a novel Arabidopsis thaliana QTL interacting with the genetic background. PLoS Genet 9(1):e1003289. https://doi.org/10.1371/journal. pgen.1003289

Michaels SD, Amasino RM (1999) FLOWERING LOCUS C encodes a novel MADS domain protein that acts as a repressor of flowering. Plant Cell 11(5):949-956. https://doi. org/10.1105/tpc.11.5.949

Michaels SD, Amasino RM (2001) Loss of FLOWERING LOCUS $C$ activity eliminates the late-flowering phenotype of FRIGIDA and autonomous pathway mutations but not responsiveness to vernalization. Plant Cell 13(4):935-941. https://doi.org/10.1105/tpc.13.4.935

Mizoguchi T, Wright L, Fujiwara S, Cremer F, Lee K, Onouchi H, Mouradov A, Fowler S, Kamada H, Putterill J, Coupland G (2005) Distinct roles of GIGANTEA in promoting flowering and regulating circadian rhythms in Arabidopsis. Plant Cell 17(8):2255-2270. https://doi.org/10.1105/tpc.105.033464

Moon J, Suh SS, Lee H, Choi KR, Hong CB, Paek NC, Kim SG, Lee I (2003) The SOC1 MADS-box gene integrates vernalization and gibberellin signals for flowering in Arabidopsis. Plant J 35(5):613-623. https://doi.org/10.1046/j.1365-313 X.2003.01833.X

Neff MM, Neff JD, Chory J, Pepper AE (1998) dCAPS, a simple technique for the genetic analysis of single nucleotide polymorphisms: experimental applications in Arabidopsis thaliana genetics. Plant J 14:387-392. https://doi. org/10.1046/j.1365-313X.1998.00124.X

Neff MM, Turk E, Kalishman M (2002) Web-based primer design for single nucleotide polymorphism analysis. Trends Genet 18:613-615. https://doi.org/10.1016/S0168-9525(02)028202

Nelson MN, Książkiewicz M, Rychel S, Besharat N, Taylor CM, Wyrwa K, Jost R, Erskine W, Cowling WA, Berger JD, Batley J, Weller JL, Naganowska B, Wolko B (2017) The loss of vernalization requirement in narrow-leafed lupin is associated with a deletion in the promoter and de-repressed expression of a Flowering Locus $T$ (FT) homologue. New Phytol 213:220-232. https://doi.org/10.1111/nph.14094

Nirenberg HI, Feiler U, Hagedorn G (2002) Description of Colletotrichum lupini comb. nov. in modern terms. Mycologia 94:307-320. https://doi.org/10.2307/3761809

Noh B, Lee SH, Kim HJ, Yi G, Shin EA, Lee M, Jung KJ, Doyle MR, Amasino RM, Noh YS (2004) Divergent roles of a pair of homologous jumonji/zinc-finger-class transcription factor proteins in the regulation of Arabidopsis flowering time. Plant Cell 16(10):2601-2613. https://doi.org/10.1105 /tpc.104.025353

O'Rourke JA, Yang SS, Miller SS, Bucciarelli B, Liu J, Rydeen A, Bozsoki Z, Uhde-Stone C, Tu ZJ, Allan D, Gronwald JW, Vance CP (2013) An RNA-Seq transcriptome analysis of orthophosphate-deficient white lupin reveals novel insights into phosphorus acclimation in plants. Plant Physiol 161: 705-724. https://doi.org/10.1104/pp.112.209254

Park J, Nguyen KT, Park E, Jeon JS, Choi G (2013) DELLA proteins and their interacting RING finger proteins repress gibberellin responses by binding to the promoters of a subset of gibberellin-responsive genes in Arabidopsis. Plant Cell 25(3):927-943. https://doi.org/10.1105/tpc.112.108951

Phan HTT, Ellwood SR, Adhikari K, Nelson MN, Oliver RP (2007) The first genetic and comparative map of white lupin (Lupinus albus L.): identification of QTLs for anthracnose resistance and flowering time, and a locus for alkaloid content. DNA Res 14:59-70. https://doi.org/10.1093 /dnares/dsm009

Pose D, Yant L, Schmid M (2012) The end of innocence: flowering networks explode in complexity. Curr Opin Plant Biol 15(1):45-50. https://doi.org/10.1016/j.pbi.2011.09.002

Raman R, Cowley R, Raman H, Luckett DJ (2014) Analyses using SSR and DArT molecular markers reveal that Ethiopian accessions of white lupin (Lupinus albus L.) represent a unique genepool. Open Journal of Genetics 04:87-98. https://doi.org/10.4236/ojgen.2014.42012

Sheldon CC, Jean Finnegan E, James Peacock W, Dennis ES (2009) Mechanisms of gene repression by vernalization in Arabidopsis. Plant J 59(3):488-498. https://doi.org/10.1111 /j.1365-313X.2009.03883.x

Shindo C, Aranzana MJ, Lister C, Baxter C, Nicholls C, Nordborg M, Dean C (2005) Role of FRIGIDA and FLOWERING LOCUS $C$ in determining variation in flowering time of Arabidopsis. Plant Physiol 138(2):1163-1173. https://doi. org/10.1104/pp.105.061309

Simpson GG (2004) The autonomous pathway: epigenetic and post-transcriptional gene regulation in the control of Arabidopsis flowering time. Curr Opin Plant Biol 7(5):570574. https://doi.org/10.1016/j.pbi.2004.07.002

Solovyev V (2004) Statistical approaches in eukaryotic gene prediction. In: Handbook of statistical genetics. John Wiley \& Sons, Ltd, Hoboken. https://doi.org/10.1002/0470022620. bbc06

Song YH, Smith RW, To BJ, Millar AJ, Imaizumi T (2012) FKF1 conveys timing information for CONSTANS stabilization in photoperiodic flowering. Science 336(6084):1045-1049. https://doi.org/10.1126/science.1219644

Sung S, Amasino RM (2004) Vernalization in Arabidopsis thaliana is mediated by the PHD finger protein VIN3. 
Nature 427(6970):159-164. https://doi.org/10.1038 /nature02195

Święcicki W Developments in L. albus breeding. In: 4th International Lupin Conference, Geraldton, Western Australia, 1986. International Lupin Association, Canterbury, New Zealand and Department of Agriculture, Western Australia, pp 14-19

Święcicki W, Święcicki WK (1995) Domestication and breeding improvement of narrow-leafed lupin (L. angustifolius L.). J Appl Genet 36(2):155-167

Takeshima R, Hayashi T, Zhu J, Zhao C, Xu M, Yamaguchi N, Sayama T, Ishimoto M, Kong L, Shi X, Liu B, Tian Z, Yamada T, Kong F, Abe J (2016) A soybean quantitative trait locus that promotes FLOWERING under long days is identified as FT5 a, a FLOWERING LOCUS Tortholog. J Exp Bot 67(17):5247-5258. https://doi.org/10.1093/jxb/erw283

Taylor CM, Kamphuis LG, Zhang W, Garg G, Berger JD, Mousavi-Derazmahalleh M, Bayer PE, Edwards D, Singh $\mathrm{KB}$, Cowling WA, Nelson MN (2019) INDEL variation in the regulatory region of the major flowering time gene LanFTc1 is associated with vernalization response and flowering time in narrow-leafed lupin (Lupinus angustifolius L.). Plant Cell Environ 42(1):174-187. https://doi. org/10.1111/pce. 13320

Toth R, Kevei E, Hall A, Millar AJ, Nagy F, Kozma-Bognar L (2001) Circadian clock-regulated expression of phytochrome and cryptochrome genes in Arabidopsis. Plant Physiol 127(4):1607-1616. https://doi.org/10.1104/pp.010467

Untergasser A, Nijveen H, Rao X, Bisseling T, Geurts R, Leunissen JAM (2007) Primer3Plus, an enhanced web interface to Primer3. Nucleic Acids Res 35:W71-W74. https://doi.org/10.1093/nar/gkm306
Valverde F, Mouradov A, Soppe W, Ravenscroft D, Samach A, Coupland G (2004) Photoreceptor regulation of CONSTANS protein in photoperiodic flowering. Science 303(5660): 1003-1006. https://doi.org/10.1126/science.1091761

Vipin CA, Luckett DJ, Harper JDI, Ash GJ, Kilian A, Ellwood SR, Phan HTT, Raman H (2013) Construction of integrated linkage map of a recombinant inbred line population of white lupin (Lupinus albus L.). Breed Sci 63:292-300. https://doi. org/10.1270/jsbbs.63.292

Voorrips RE (2002) MapChart: software for the graphical presentation of linkage maps and QTLs. J Hered 93:77-78. https://doi.org/10.1093/jhered/93.1.77

Watanabe S, Xia Z, Hideshima R, Tsubokura Y, Sato S, Yamanaka N, Takahashi R, Anai T, Tabata S, Kitamura K, Harada K (2011) A map-based cloning strategy employing a residual heterozygous line reveals that the GIGANTEA gene is involved in soybean maturity and flowering. Genetics 188(2): 395-407. https://doi.org/10.1534/genetics.110.125062

Weller JL, Ortega R (2015) Genetic control of flowering time in legumes. Front Plant Sci 6:207. https://doi.org/10.3389 /fpls.2015.00207

Zhang H, van Nocker S (2002) The VERNALIZATION INDEPENDENCE 4 gene encodes a novel regulator of FLOWERING LOCUS C. Plant J 31(5):663-673. https://doi.org/10.1046/j.1365-313X.2002.01380.x

Zhang H, Ransom C, Ludwig P, van Nocker S (2003) Genetic analysis of early flowering mutants in Arabidopsis defines a class of pleiotropic developmental regulator required for expression of the flowering-time switch FLOWERING LOCUS C. Genetics 164(1):347-358 